\title{
Common and Newly Identified Foliar Diseases of Seed-Producing Lucerne in France
}

C. Leyronas, UMR Epidémiologie végétale et Ecologie des populations, INA PG-INRA, BP 01, 78850 ThivervalGrignon, France; L. M. Broucqsault, FNAMS, Ferme de Marcellas, 26800 Etoile, France; and G. Raynal, UMR Epidémiologie végétale et Ecologie des populations INA PG-INRA, France

\begin{abstract}
Leyronas, C., Broucqsault, L. M., and Raynal, G. 2004. Common and newly identified foliar diseases of seed-producing lucerne in France. Plant Dis. 88:1213-1218.

A 4-year survey of seed-producing lucerne fields in the three main production regions of France, representing 10.000 ha and three types of climates, confirmed the presence of the foliar pathogens Pseudopeziza medicaginis, Ascochyta imperfecta, Stemphylium spp., Leptosphaerulina briosiana, and Uromyces striatus. Surprisingly, A. imperfecta often was found in association with Stemphylium-like symptoms. Further investigation revealed the presence of fungi until now only rarely found or unreported in France, such as Leptotrochila medicaginis, Cercospora medicaginis, and Stagonospora meliloti. The results showed that $P$. medicaginis and A. imperfecta were present on more than $50 \%$ of the samples. U. striatus and C. medicaginis also commonly were found and infected about $25 \%$ of the samples. L. medicaginis occurred primarily in the Southwest region.
\end{abstract}

In France, a total of 500,000 ha are planted to lucerne (Medicago sativa $\mathrm{L}$.), of which about 10,000 ha are for seed production. In 2001, France was the first producer of lucerne seed in Europe with 12,826 ha, followed by Italy $(8,847$ ha) and Spain (6,612 ha) (French Association for Seeds and Plants, GNIS, personal communication). The French areas of seedproducing lucerne are distributed among the three main regions of production. Centre-West $(\mathrm{CW})$ is the most important region, with half of the lucerne seed production fields (Fig. 1). In South-West (SW) and South-East (SE), there are about 3,500 and 1,700 ha, respectively (1). Each region has its own climate. The $\mathrm{CW}$ is a temperate oceanic climate, with regular rainfalls, whereas SE climate is Mediterranean, with very hot summers and irregular thunder storms. During May, June, and July, the growing period of lucerne, SW climate is as hot as SE climate but with less violent thunderstorms (national meteorological data from Fédération Nationale des Agriculteurs Multiplicateurs de Semences [FNAMS] experimental stations, personal communication; Figs. 2 and 3 ).

A certain number of pathogenic fungi develop in seed production fields where the leaves are present for a long period. In the South of France, seed production fields

Corresponding author: C. Leyronas
E-mail: leyronas@grignon.inra.fr

Accepted for publication 17 June 2004.

Publication no. D-2004-0913-01R

C 2004 The American Phytopathological Society are not cut between the vegetative regrowth in the spring and harvest in late July to early August. However, in areas where the weather and soil conditions are highly favorable for growth, as in the CW region, plants generally are cut once in late April or May. In North America and Australia, the most frequently cited fungi on lucerne are Phoma medicaginis Malbr. \& Roum. in Roum. var. medicaginis, Pseudopeziza medicaginis (Lib.) Sacc., Stemphylium spp., Cercospora medicaginis Ellis \& Everh., and Leptosphaerulina briosiana (Pollaci) J. H. Graham \& Luttrell $(2,3,6,10,11,22)$. To this list should be added the rust fungus Uromyces striatus J. Schröt, which is often the subject of special study (21). In France, in the 1970s, a survey on fodder lucerne showed that $P$. medicaginis, Ascochyta imperfecta Pk., and Stemphylium spp. were the most common foliar diseases. At the same time, $P$. medicaginis was the second most important disease in southern and eastern Europe (the first was Verticillium albo-atrum Reinke \& Berthold). A. imperfecta was reported as the third most common pathogen or was not important (16). Another survey conducted during 10 years until 1981, based on the voluntary submission of samples, found that $A$. imperfecta was as frequent as V. albo-atrum (14\% of samples). $L$. briosiana and $P$. medicaginis were present in 6 and $4 \%$ of samples, respectively. Stemphylium botryosum and U. striatus were present in $2.6 \%$ of samples (12). The major disadvantage of this survey was the bias of using voluntary submission of samples, resulting in common and wellknown diseases being underestimated. A survey using a rational sample collection was needed in order to identify the main diseases of lucerne and whether new emergent diseases, unknown in France, were present.

In response to a request of the FNAMS (National Federation of Seed Growers) to determine the effects of diseases on seed yield, a 4-year survey was undertaken in producer fields to identify agents responsible for necrotic spots on lucerne leaves. This article reports the results of a 4-year survey of the pathogenic fungi commonly found on lucerne, and other fungi not described previously in France which may be significant.

\section{MATERIALS AND METHODS}

Survey. The survey was conducted from 2000 to 2003 in the three main areas of seed production in France: SE, SW, and $\mathrm{CW}$ (Fig. 1). SE region included the Ardèche, Drôme, and Hérault departments. SW region was composed of the Tarn, Gers, and Aude departments. CW was represented by the Vienne, Deux Sèvres, Maine et Loire, and Vendée departments. SE was not surveyed in 2003.

Observations were made on a total of 100 seed-producing or trial plots from which samples (stems with leaves) were taken, sometimes several times, during the season. Fields were chosen according to the cultivar, the distance from the experimental station, and the seed growers' cooperation in the survey. To be representative of each region, as wide a range of cultivars as possible was chosen. Moreover, the fields near experimental stations were chosen so that samples could be collected several times during the season. Among the fields sampled, some of them were the same from year to year.

Samples were made from the start of flowering until the brown-pod stage (late May to late July). When most foliar diseases appeared and developed in each field, 20 stems were collected randomly. The most representative stem of the general state of health of the field was chosen. Precise diagnosis rarely were possible by visual examination in the field; therefore, the chosen stems were wrapped in paper and sent by rapid courier service to the Plant Pathology laboratory of the National Institute of Agronomic Research (INRA) in Grignon for identification.

Diagnosis. For each leafy stem, about 15 leaflets representative of the state of 
health of the entire stem were observed under the dissecting microscope to establish an initial diagnosis. The leaflets then were incubated for 48 to $72 \mathrm{~h}$ on moist absorbent paper in petri dishes, at room temperature, to encourage the development of typical reproductive structures in order to confirm the initial diagnosis. We used key characteristics as described by Stuteville and Erwin (19) and Raynal et al. (15) to identify the fungi which were recorded as present or absent in each stem. In most of the cases, there were mixed infections on leaves. The relative importance of each fungus compared with the others was not evaluated; however, those cases where a single fungus dominated the complex of foliar pathogens were noted. We didn't analyze differences in frequencies of each pathogen during the growing season because the objective of the study was to obtain a broad overview of the diseases present in each region.

Special cases. Leaves suspected of bearing pepper spot (A. imperfecta) were placed on moist paper in a petri dish covered with a dish containing potato dextrose agar medium (PDA) and incubated under natural light at room temperature (15).
Ejected ascospores were collected on PDA and the resulting colonies identified.

In the case of $A$. imperfecta, isolates from typical and atypical symptoms were grown on PDA. The colonies were compared with Ascochyta spp. of pea (A. pinodes, A. pisi, and A. pinodella) supplied by the National Station of Seed Trials (SNES, Beaucouzé, France). In addition, 2-month-old plants of the lucerne cv. Europe were inoculated with isolates from the two types of symptoms (collected in June 2002, in lucerne fields of Drôme department, SE). The suspension concentration was $2 \times 10^{6}$ spores $/ \mathrm{ml}$. The plants were incubated in a growth chamber with high humidity with $12 \mathrm{~h}$ of light and a temperature of $20^{\circ} \mathrm{C}$. Symptoms were observed after 1 and 2 weeks.

Statistical analysis. Data concerning $P$. medicaginis, A. medicaginis, U. striatus, C. medicaginis, and Stemphylium spp. in 2000, 2001, and 2002 were subjected to a $\chi^{2}$ test: proportions of infected stems of each year were compared between the three regions of production. The $\chi^{2}$ test identifies the fungi which contribute the most to the distribution differences between regions. For L. briosiana, Leptotro- chila medicaginis (Fuckel) H. Schüepp, Stagonospora meliloti (Lasch) Petr., and Stemphylium botryosum Wallr. cold biotype, numbers were not sufficient to apply a $\chi^{2}$ test. Then, for each year and each pair of regions, exact probability Fisher tests were performed to compare proportions of a given fungus between the two regions. An exact probability Fisher test also was performed to compare the proportions of $P$. medicaginis between years in the $\mathrm{CW}$. Differences described in the text are significant at $P<0.05$ unless otherwise indicated. Analyses were performed with Statview software (version 5; SAS Institute Inc., Cary, NC).

\section{RESULTS AND DISCUSSION}

A total of 700 lucerne stems were subjected to a detailed diagnostic study. Each year, 103 to 289 samples were analyzed with 261, 301, and 138 samples collected from the $\mathrm{SE}, \mathrm{SW}$, and $\mathrm{CW}$ regions, respectively.

The study revealed the usual pathogens of lucerne in France ( $P$. medicaginis, A. imperfecta, U. striatus, and Stemphylium spp.), known in particular for their association with lucerne grown as a forage crop;

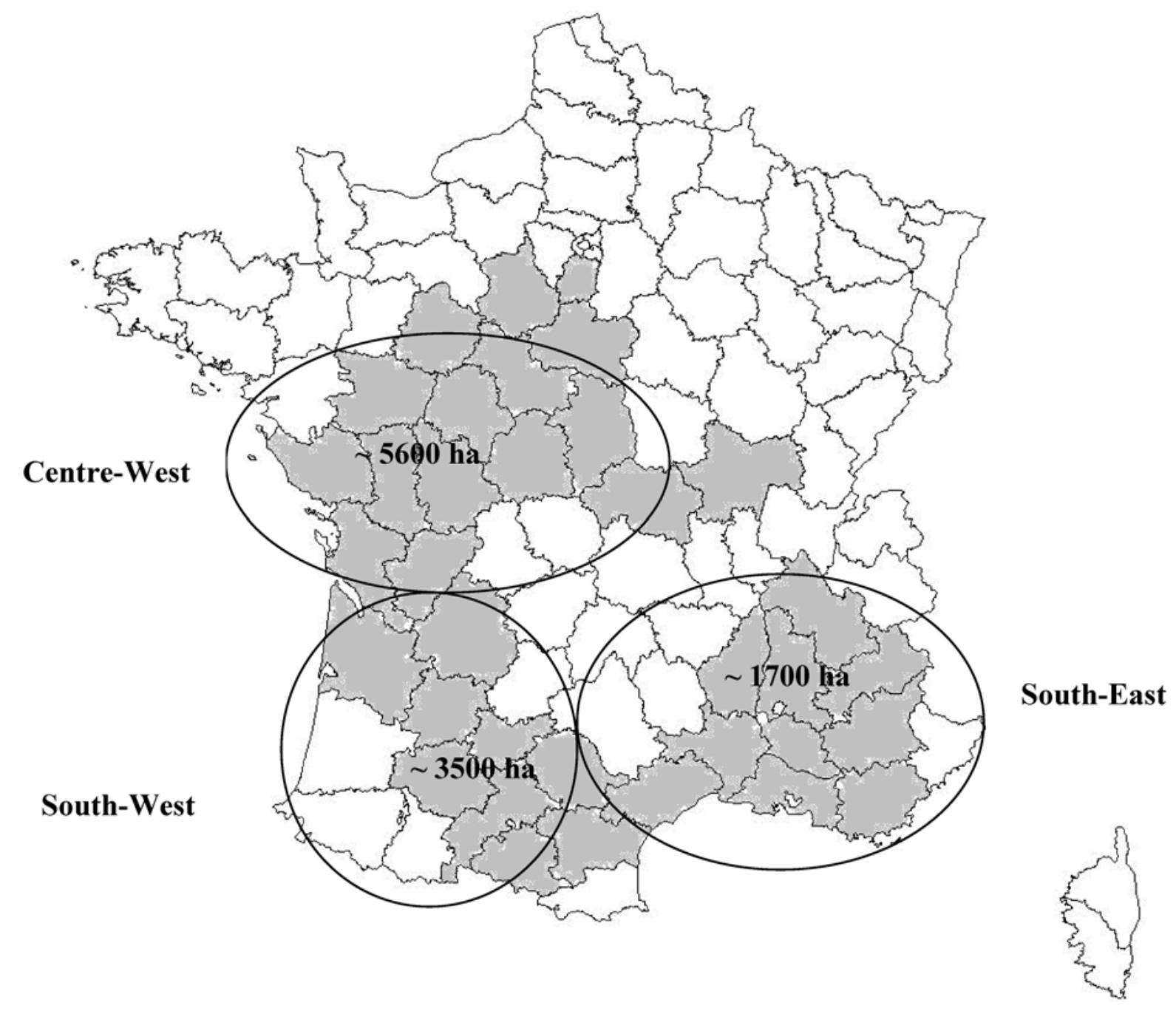

Fig. 1. The three main French regions of lucerne seed production (GNIS values 2002). 
only a Verticillium sp. was not found in areas of seed-producing lucerne $(13,15$; Table 1). C. medicaginis, considered until now to be uncommon in France, was one of the most regularly encountered pathogens in this survey. Comparison of infected stem proportion distribution for each year shows that there were significant differences between regions (2000: $\chi^{2}=23.1, P$ $=0.0032 ; 2001: \chi^{2}=33.2, P<0.0001$; 2002: $\left.\chi^{2}=121.3, P<0.0001\right)$. Leptosphaerulina briosiana frequently was found in $\mathrm{CW}$, but was found infrequently in SW and not found in SE. Because of the low recovery, this fungus could not be compared statistically with the five other common pathogens in the $\chi^{2}$ test.

$P$. medicaginis was one of the fungi most frequently encountered on leaves. Of the stems analyzed, 58\% showed symptoms of $P$. medicaginis. The fungus was distributed evenly throughout the regions and over the 4 years of the study, from May to harvest (Table 1). In the first 3 years of survey, the proportions of stems infected by $P$. medicaginis were not a major contributor to the distribution differences between regions. In 2003, a particularly hot and dry year (Figs. 2 and 3), $P$. medicaginis was less prevalent or even absent in samples from the $\mathrm{CW}$ region $(P$ [Fisher] $<0.0010$ compared with the three previous years). Sometimes symptoms of leaf spots and necrosis in the field were due almost entirely to $P$. medicaginis, with spots due to other fungi very infrequent. Leaves with typical symptoms of $P$. medicaginis were found most frequently in the SW and CW regions. Harmfulness of this disease on seed yield has been reported (4).

For a reliable identification of A. imperfecta, observation of the pycnidia that develop on the irregular-shaped black spots found on leaves and, occasionally, stems often is necessary. Without incubation, it is possible to confuse this fungus with others, such as $P$. medicaginis before apothecium development, or even C. medicaginis. Of the samples in this study, 66\% showed symptoms of A. imperfecta (Table 1). This fungus is not a major contributor to the distribution differences between regions. In addition to the typical symptoms, described as black spots on the leaves and stems, throughout the study, and on all cultivars, we regularly observed other symptoms that were more difficult to interpret. Pycnidia appear on large lesions composed of concentric circles of various shades, similar to those generally attributed to Stemphylium sp., also in roughly concentric circles. These pycnidia liberate spores that are identical to those of $A$. imperfecta isolated from typical black spots. Colonies isolated from typical black spots and those isolated from concentric spots were dissimilar in morphology of mycelia. The fungus isolated from atypical symptoms also was dissimilar from isolates of Ascochyta of pea. We were unable to reproduce the two types of symptoms using artificial inoculation. Plants inoculated produced black lesions on leaves 6 days after inoculation with all isolates of $A$. imperfecta tested. Two weeks later, the lesions were larger and more numerous, but there was no difference between the symptoms produced by the colonies isolated for the different types of leaf spot. At present, we do not know the cause of the concentric circles, apparently not observed with other Ascochyta spp. Further experiments are needed to determine whether these atypical symptoms are caused by particular microclimatic conditions (temperature, humidity, or photoperiod) in the leaf canopy.
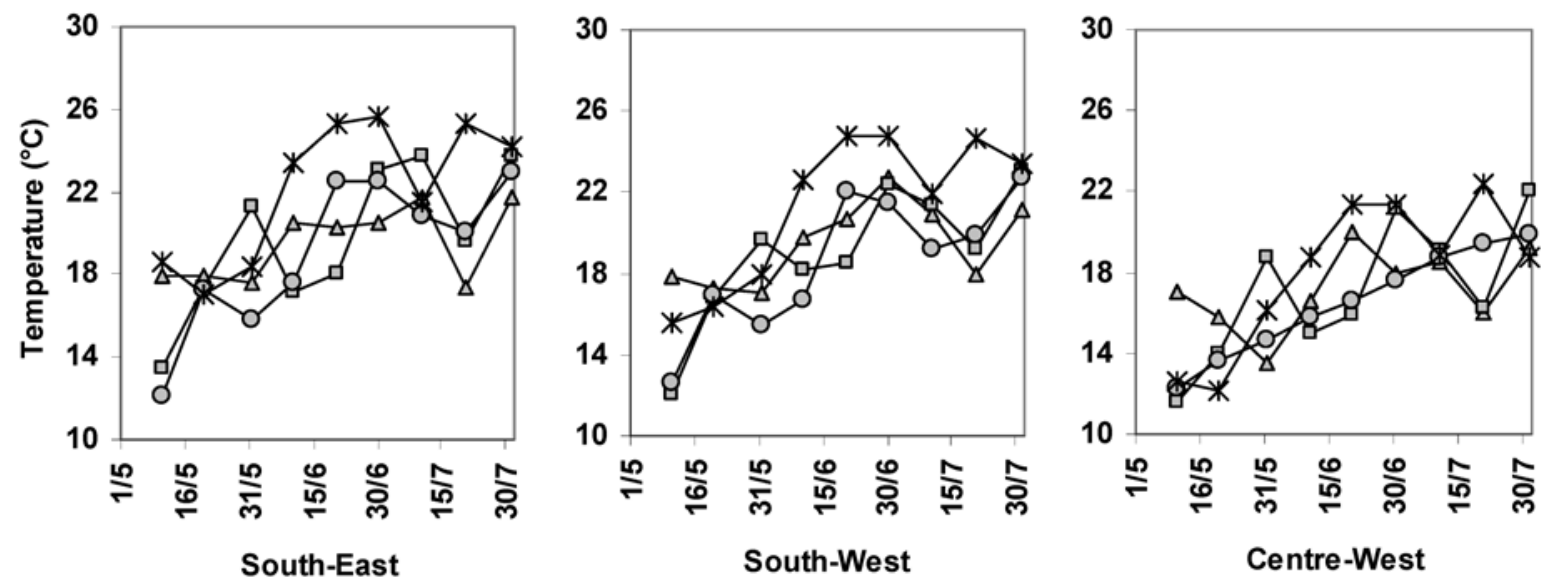

Fig. 2. Mean decade temperatures of May, June, and July, in the three main regions of seed-producing lucerne, during the 4 years of survey. (triangle, 2000; square, 2001; circle, 2002; star, 2003).
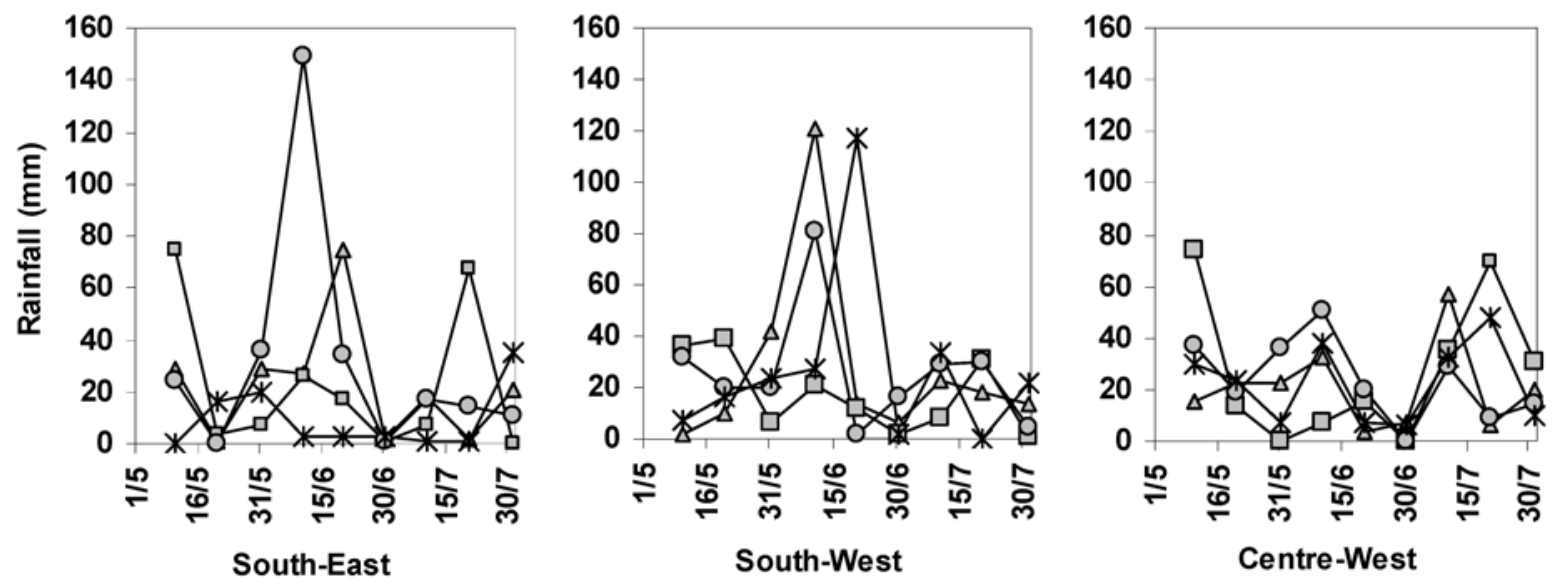

Fig. 3. Decade rainfalls of May, June, and July in the three main regions of seed-producing lucerne, during the 4 years of survey. (triangle, 2000; square, 2001; circle, 2002; star, 2003). 
As a general rule, the globular, pluricellular spores typical of Stemphylium spp. appear on practically all leaflets after incubation for $72 \mathrm{~h}$. However, this fungus was present everywhere throughout the year on all cultivars (Table 1). It is not a major contributor to the distribution differences between regions. Symptoms typical of those produced by species of Stemphylium described in the literature (19) are spots with concentric brown rings. Such symptoms were observed frequently, mainly on leaves in the bottom of the canopy, with typical sporulation after incubation. However, this sporulation extended well beyond the lesions, suggesting that the lesions were not in fact caused by Stemphylium spp. Moreover, as mentioned earlier, $A$. imperfecta (or another Ascochyta sp.) may produce similar symptoms. Experience has shown that it is very risky to attribute such visual symptoms as being solely due to Stemphylium spp., as is done usually. The only cases in which it was possible to attribute the symptoms to Stemphylium spp. were those where the leaves bore dried out white spots with a dark edge. In these cases, the spores appeared only within the white area. This was the case for plants from the $\mathrm{CW}$ and the SE regions. Proportions of infected stems of the CW were significantly higher than the SW proportions in $2002(P$ [Fisher] $=0.0019)$ and $2003(P$ [Fisher] $=0.0133)$. No significant differences were observed among the three regions in 2000 and 2001. These symptoms could be due to the cold biotype of Stemphylium botryosum described by Stuteville and Erwin (19). The spots with concentric rings are more likely to be due to the warm biotype when they are not due to a particular Ascochyta sp.

Rust caused by $U$. striatus was a very common disease in SE France, the hottest region among the three surveyed (Figs. 2 and 3), where it appeared from May on- ward and heavily infected crops $(80 \%$ of the samples in 2001 were infected; Table $1)$. Indeed, $U$. striatus was the major contributor to the overall $\chi^{2}$ value for the 3 years of survey and was always highest in the SE. It was much less common in the other two areas of production, however, where it appeared at the end of the season, apart from in exceptional years such as 2001 when, even in the CW, $36 \%$ of samples bore pustules. These powdery rustbrown pustules first appear on the lower surface of the leaves, then over the entire leaf surface. In heavy attacks or at the end of the season, stems also were affected. This disease can lead to significant defoliation and, consequently, affects the seed yield. FNAMS showed that fungicide treatments can be very useful in controlling rust and may significantly increase seed yield (4).

Pepper spot symptoms caused by Leptosphaerulina briosiana are characterized by small specks with a black edge and pale center, often surrounded by a yellow halo. At first, only a few small spots may be present, and these easily may be confused with those produced by other pathogens. Therefore, it is imperative that the sample be alive and well preserved in order to be able to trap and identify this fungus. For this reason, it is probable that the number of samples with $L$. briosiana was underestimated. This pathogen typically is found in the CW. In the 2002 survey, all 17 of the samples carrying L. briosiana came from this region. On average, a quarter of the samples from the CW were affected by pepper spot, whereas it was virtually nonexistent in the other production zones (Table 1). Indeed, proportions of stems infected by $L$. briosiana in the $\mathrm{CW}$ were significantly higher than proportions coming from the SE and the SW in $2000(P$ $[\text { Fisher }]_{\mathrm{CW} \_\mathrm{SW}}=0.146$ and $P[\text { Fisher }]_{\mathrm{CW} \_\mathrm{SE}}$ $<0.0001), 2002\left(P[\text { Fisher }]_{\text {CW_Sw }}\right.$ and $P$ $\left.[\text { Fisher }]_{\text {CW_SE }}<0.0001\right)$, and $2003(P$ $\left.[\text { Fisher }]_{\text {CW_SW }}<0.0001\right)$. A cool, moist climate favors $L$. briosiana sporulation. Moreover, the greatest damage occurs on young leaves of regrowth (19). Therefore, the $\mathrm{CW}$ region with its oceanic climate, where fields always are cut 2 months before harvest, is an ideal region for $L$. briosiana development. Apart from defoliation, this fungus can greatly increase the concentration of coumestrol (an estrogen analogue) in the leaves, which can be a problem if the lucerne is eaten as forage (15).

During this survey, we found several fungi previously described as rare or unreported in France (9). The symptoms caused by $C$. medicaginis easily can be confused with those of Stemphylium spp. or A. imperfecta when they are observed with the naked eye. These symptoms are brown, fairly large lesions. In humid conditions, long gray conidia are produced on oblong conidiophores, resulting in a hairy appearance under the dissecting microscope (19). Therefore, it is quite easy to distinguish this fungus from the others of the parasite complex. On dry lesions, it even is possible to see the remains of the conidiophores forming a gray powder viewable with the naked eye. Perhaps it is because of its resemblance to the other diseases in the field that little attention has been paid to $C$. medicaginis; yet, seedproducing lucerne are favorable fields for C. medicaginis. Indeed, this fungus needs high humidity and relatively high temperature $\left(24\right.$ to $\left.28^{\circ} \mathrm{C}\right)$ (19). These conditions can be found in the dense canopy of seedproducing lucerne from June to harvest in all the French production regions. C. medicaginis is found in all three production zones, its importance varying among years. In 2001, it was underrepresented in the SE and overrepresented in the $\mathrm{CW}$; whereas, in 2002, it was overrepresented in the SW

Table 1. Pathogens associated with lucerne leaves from seed production fields from three regions in France

\begin{tabular}{|c|c|c|c|c|c|c|c|c|c|c|c|c|c|c|c|}
\hline \multirow[b]{3}{*}{ Pathogens } & \multicolumn{14}{|c|}{ Percentage of infected samples ${ }^{a}$} & \multirow[b]{3}{*}{$\mathrm{OWM}^{\mathrm{e}}$} \\
\hline & \multicolumn{4}{|c|}{ South-East ${ }^{b}$} & \multicolumn{5}{|c|}{ South-West ${ }^{c}$} & \multicolumn{5}{|c|}{ Centre-West $^{\mathrm{d}}$} & \\
\hline & 2000 & 2001 & 2002 & WM & 2000 & 2001 & 2002 & 2003 & WM & 2000 & 2001 & 2002 & 2003 & WM & \\
\hline Pseudopeziza medicaginis & 85 & 82 & 52 & 66 & 64 & 88 & 53 & 25 & 50 & 69 & 72 & 74 & 0 & 62 & 58 \\
\hline Ascochyta imperfecta & 65 & 44 & 83 & 72 & 65 & 39 & 56 & 72 & 62 & 61 & 64 & 65 & 61 & 63 & 66 \\
\hline Uromyces striatus & 50 & 80 & 43 & 51 & 11 & 18 & 2 & 14 & 10 & 6 & 36 & 2 & 0 & 9 & 25 \\
\hline Stemphylium sp. & 58 & 44 & 68 & 61 & 44 & 64 & 73 & 55 & 59 & 39 & 36 & 7 & 38 & 27 & 54 \\
\hline Cercospora medicaginis & 36 & 4 & 2 & 11 & 17 & 30 & 27 & 56 & 35 & 22 & 44 & 2 & 22 & 20 & 23 \\
\hline Leptosphaerulina briosiana & 0 & 0 & 0 & 0 & 7 & 3 & 0 & 2 & 3 & 24 & 12 & 37 & 39 & 28 & 7 \\
\hline Leptotrochila medicaginis & 1 & 0 & 0 & 0 & 8 & 39 & 41 & 9 & 22 & 14 & 8 & 0 & 11 & 8 & 11 \\
\hline Stagonospora meliloti & 4 & 4 & 1 & 3 & 1 & 15 & 26 & 2 & 11 & 0 & 0 & 2 & 0 & 1 & 6 \\
\hline Stemphylium botryosum ${ }^{\mathrm{f}}$ & 1 & 4 & 8 & 6 & 1 & 0 & 5 & 3 & 3 & 10 & 4 & 20 & 28 & 14 & 6 \\
\hline Total of analyzed stems & 69 & 45 & 147 & 261 & 70 & 33 & 96 & 102 & 301 & 49 & 25 & 46 & 18 & 138 & 700 \\
\hline
\end{tabular}

a A sample consisted of a stem with at least 15 leaflets A fungus was recorded as present on a sample if it was present on at less one leaflet or on the stem. Weighted mean (WM) was calculated in order not to give to much influence to the mean to small samples (total number of infected stems of each region over the 3 or 4 years of survey is divided by the total number of stems of the region).

${ }^{\mathrm{b}}$ South-East region is composed of the Ardèche, Drôme, and Hérault departments.

${ }^{\mathrm{c}}$ South-West region is composed of the Tarn, Gers, and Aude departments.

${ }^{\mathrm{d}}$ Centre-West is represented by the Vienne, Deux Sèvres, Maine et Loire, and Vendée departments.

e Overall weighted mean (OWM): total number of stems infected by a given pathogen on the total numbers of analyzed stems over the survey.

${ }^{\mathrm{f}}$ Cold biotype of $S$. botryosum differs from Stemphylium spp. by dried out spots with a dark edge. Spores appeared only within the white area. 
and underrepresented in the SE. In 2003, more than $50 \%$ of stems were infected by C. medicaginis in the SW region (Table 1). The cultivars on which we identified $C$. medicaginis were Bella, Comète, Diane, Europe, Fee, Harpe, Pecy, Planète, Sanditi, Sitel, Symphonie, Tango, and Zenith. Few articles are dedicated to this pathogen alone, but it often is cited as one of the components of the parasite complex of lucerne in several countries $(6,8,17,18$, 20,22). Finally, we found a few cases in which $C$. medicaginis was the dominant fungus, with spots covering a large part of the leaf area. However, it was now the fifth most frequent fungus, after A. imperfecta, $P$. medicaginis, U. striatus, and Stemphylium spp., in the surveyed regions, even if its presence was more irregular.

Leptotrochila medicaginis rarely have been reported in France until now. As described by Stuteville and Erwin (19), the first symptoms to appear on affected leaves are one or more yellow halos pitted with small black points corresponding to pycnidia apertures. From these exudes a pale yellow gelatinous mass containing the conidia. In humid conditions, apothecia appear on the blackening halos about 10 days later. These contained a great many paraphyses. In the 1990s, a small number of lucerne samples sent to the laboratory for identification showed spots due to $L$. medicaginis (yellow leaf blotch). From 2000 onward, it was no longer possible to consider this presence as incidental, especially in the SW: there were significant differences between proportions of infected stems between the SW and the two other regions in 2001 ( $P$ [Fisher $]_{\mathrm{SW}_{-} \mathrm{SE}}<$ $\left.0.0001 ; P[\text { Fisher }]_{\mathrm{SW}_{\mathrm{CW}}}=0.0076\right)$ and $2002\left(P \quad[\text { Fisher }]_{\text {SW_SE }}<0.0001 ; P\right.$ [Fisher] $\left.]_{\mathrm{SW}_{\mathrm{CW}}}<0.0001\right)$. In 2001 and 2002, of the 129 samples examined from the SW region, $40 \%$ had yellow leaf blotch (Table 1). This disease was found in 15 of the 16 fields monitored. We also found a few cases in plots in the $\mathrm{CW}$, and very few or none at all in the SE. The cultivars affected were diverse: Alizé, Bella, Derby, Diane, Europe, Fee, Mercedes, Nogara, Pecy, Red Green, Sanditi, San Isidro, Sitel, Tango, and Victoria. We have not noted any differences in the presence of this pathogen between years of production. Attacks on fields in the first year of production were similar to those on fields in year 2 and year 3. Few studies have been undertaken on this fungus in France, even though we have observed that whole plots easily can be affected by this disease. Moreover, in the United States and some East European countries, it is known to cause heavy defoliation and losses in seed yield (19). Therefore, it appears that this fungus should now be considered as a major pathogen in the foliar parasite complex of lucerne, especially in the SW region of France. However, we do not have an ex- planation as to why this parasite has spread so much during the last 10 years.

Among the fungi provoking leaf spots on lucerne, Stagonospora meliloti are the ones found most sporadically. The symptoms are pale dry lesions, often fused together, on which dark pycnidia can be distinguished as small pits. In humid conditions, these exude a pale slime containing long, mostly unicellular, conidia. Isolation of this fungus was infrequent in the three regions (Table 1), but occasionally important in certain plots, as found in 2002 in the SW (16 of the 29 samples examined, coming from a plot trial, were infected). In that year, S. meliloti was, on average, just as frequent ( $27 \%$ of the samples identified) as $C$. medicaginis $(26 \%)$ in plots in the $\mathrm{SW}$, and proportions of infected stems were significantly higher than in the SE and the CW ( $P$ [Fisher] SW_SE $_{\text {S }}<0.0001 ; P$ $\left.[\text { Fisher }]_{S_{-} C_{W}}=0.0003\right)$. We only took note of the foliar symptoms caused by $S$. meliloti in the present study, but this fungus is known to attack roots also, causing root rot in lucerne and reducing plant density during the years of cultivation in certain regions of the world (California, New Zealand, and Australia; 7,19). Therefore, it would be advisable to monitor the plots that are heavily infected by this fungus in France to look for evidence of root rot.

Conclusion. This survey, which included detailed diagnostic examination, has enabled us to confirm the presence of the most common foliar pathogens of seedlucerne in France. Other fungi, previously indicated as uncommon or absent in France, also were detected. These fungi may have been overlooked in the past due to the similarity of their macroscopic symptoms to those induced by the more common pathogens. The few studies dealing with diseases of lucerne in France are not recent and generally concern forage lucerne. In the $1980 \mathrm{~s}, A$. imperfecta, $P$. medicaginis, and Stemphylium spp. were the most common fungi. It was known that U. striatus and Leptosphaerulina briosiana were localized in the South and the West of France, respectively (13). Our study shows that, in addition to these fungi, $C$. medicaginis can be considered a common fungus in French seed-producing lucerne. Concerning Leptotrochila medicaginis and Stagonospora meliloti, in the 1990s, their presence was considered sporadic (14). Our results clearly demonstrate that the presence of the pathogen $L$. medicaginis can no longer be ignored, especially in the SW, where heavy infections were detected. There are very few studies dealing with foliar diseases of lucerne grown for seed or forage in European countries, and France is a climatic crossroads of Europe; therefore, the data obtained in this study could be extrapolated to neighboring countries with Mediterranean or oceanic climates.

In another study by the FNAMS to determine the best timing for fungicide treat- ments against foliar pathogens, initial results show that, in 20 of 27 trials, treatments have a significant positive effect on seed yield when the pathogen complex was significant in the nontreated plots. In the other seven trials, seed production was limited by other factors whose effects hid the interest of the fungicide protection, such as unfavorable soil for lucerne culture $(4,5)$. It shows that the foliar pathogen complex of lucerne may be really harmful for seed production.

In France, the selection of lucerne cultivars against foliar diseases takes into account only the general criterion of "susceptibility to leaf spots," without distinguishing the pathogens that cause these spots (but doubtless referring to Pseudopeziza and Ascochyta spp. only). This survey, limited to seed production, shows that they are diverse and distributed unevenly: A. medicaginis and $P$. medicaginis are widely distributed, whereas Leptosphaerulina briosiana and Leptotrochila medicaginis seem to have a more regional distribution. It is improbable that resistance to one fungus will confer resistance to the others; therefore, it is possible that the cultivars selected for their field resistance in the presence of one pathogen complex may be susceptible in another area where the pathogen complex is different, or to a particular pathogen absent from the area in which selection took place. This is a possible explanation as to how $L$. medicaginis and $C$. medicaginis have been able to spread progressively to many different cultivars.

Because selection for resistance to foliar parasites is a long-term task, it is impossible to design a program that only concerns lucerne for seed production, which concerns fairly small areas. For this reason, it is important that more precise information be obtained on the extent to which attacks by these fungi, especially those provoking leaf drops or animal poisoning, are damaging to forage production.

\section{ACKNOWLEDGMENTS}

We thank all the people of FNAMS who worked in the field and made this survey possible, J. Hacquet for reviewing the manuscript, J. D. Arnaud of GNIS for providing the areas data of seedproducing lucerne, and S. Soubeyrand for statistical advice.

\section{LITERATURE CITED}

1. Anonymous. 2003. Surfaces en multiplication de semences-Récolte 2002. FNAMS Internal Document.

2. Barbetti, M. J., and Fang, C. S. 1991. Relationship between Phoma black stem severity and herbage and seed yield and coumestro content in three Medicago polymorpha var. brevispina cultivars. Aust. J. Agric. Res. 42:409-415.

3. Basu, P. K. 1976. Measuring severity of common and Stemphylium leaf spots of alfalfa for loss assessment. Plant Dis. Rep. 60:1037-1040.

4. Broucqsault, L. M. 2003. Luzerne portegraine: stratégies fongicides contre les maladies foliaires. Compte rendu d'expérimentation FNAMS, Avril 2003:14-17. 
5. Broucqsault, L. M., Leyronas, C., and Hacquet, J. 2000. Nuisibilité du complexe parasitaire sur le rendement grainier et protection fongicide de la luzerne porte-graine. Pages 375-381 in: ANPP 6th Conf. Int. Maladies Plantes, Tours

6. Campbell, C. L., and Duthie, J. A. 1990. Impact of leaf spot diseases on yield and quality of alfalfa in North Carolina. Plant Dis. 74:241-245.

7. Erwin, D. C., Khan, R. A., Ribeiro, O. K., and Lehman, W. F. 1987. Growth, sporulation, and pathogenicity of Stagonospora meliloti and selection for resistance to crown rot and leaf spot in alfalfa. Plant Dis. 71:181-185.

8. Gray, F. A., Haaland, R. L., Clark, E. M., and Ball, D. M., 1980. Diseases of alfalfa in Alabama. Plant Dis. 64:1015-1017.

9. Leyronas C., and Raynal, G. 2003. Maladies observées en France sur graminées et légumineuses fourragères pérennes. Phytoma 557:14-16.

10. Morgan, W. C., and Parbery, D. G. 1977. Effects of Pseudopeziza leaf spot disease on growth and yield in lucerne. Aust. J. Agric. Res. 28:1029-1040.

11. Nutter, F. W., Jr., and Guan, J. 2002. Quantifying alfalfa yield losses caused by foliar diseases in Iowa, Ohio, Wisconsin and Vermont. Plant Dis. 86:269-277.

12. Raynal, G. 1982. Répartition géographique et importance relative des maladies de la luzerne en France: résultats d'un enquête nationale et conseils pour la lutte. Le sélectionneur français. 30:49-56.

13. Raynal, G. 1984. Les principales maladies de la luzerne. Phytoma 360:35-37.

14. Raynal, G. 1997. Les maladies des légumineuses fourragères en France: observations sur une quinzaine d'années. 5th CIMA, ANPP, Tours.

15. Raynal, G., Gondran, J., Bournoville, R., and Courtillot, M. 1989. Ennemis et maladies des prairies. INRA.

16. Raynal, G., and Guy, P. 1977. Répartition et importance des maladies de la luzerne en France et en Europe. Fourrages 71:5-14.

17. Rizvi, S. S. A., and Nutter, F. W., Jr. 1993.
Seasonal dynamics of alfalfa foliar pathogens in Iowa. Plant Dis. 77:1126-1135.

18. Souza, P. E., Hilario, A. C., Pozza, E. A. Evangelista, A. R., and Morais, A. R. 1999. Eficienca de fungicidas de regimes de pilverizacao no contrôle de manchas foliares da alfafa. Summa Phytopathol. 25:78-80

19. Stuteville, D. L., and Erwin, D. C. 1990. Compendium of Alfalfa Diseases. 2nd ed. American Phytopathology Society, St Paul, MN.

20. Summers, C. G., and MacClellan, W. D., 1975. Effect of common leafspot on yield and quality of alfalfa in the San Joaquin Valley of California. Plant. Dis. Rep. 59:504-506.

21. Webb, D. H., and Nutter, F. W., Jr., 1997. Effects of leaf wetness duration and temperature on infection efficiency, latent period and rate of pustule appearance of rust in alfalfa. Phytopathology 87:946-950.

22. Wilcoxson, R. D., Bielenberg, O., and Bissonnette, H. L. 1973. Yield of alfalfa hay increased by control of foliar diseases. Plant Dis. Rep. 57:353-354 